\title{
Can the SC Resolution 2270 Stop North Korea's Nuclear Dilemma? From the Geneva Agreed Framework to the Washington Communiqué
}

\author{
Eric Yong Joong Lee*
}

The UN Security Council adopted Resolution 2270 against North Korea's fourth nuclear test on January 6, 2016, and its subsequent rocket launch. This resolution contains tougher sanction measures than any others adopted in the past, but is not expected to effectively stop North Korea's nuclear weapons program. This essay analyzes the critical loophole of the rule of law in global society regarding nuclear proliferation systems as well as regional governance. It further suggests legal and policy options to resolve this nuclear dilemma. The parties concerned are asked to alter the status quo of hostile co-existence and instead revert to the spirit of the Geneva Agreed Framework.

\section{Keywords}

North Korea, Nuclear Test, Resolution 2270, NPT, Six-Party Talks, Two-Track Approach, NEA-NWFZ, Kim Jong Un

\section{Genesis}

On January 6, 2016, North Korea carried out its fourth nuclear test at the Punggyeri nuclear test site, approximately 50 kilometers northwest of Kilju City, North Hamkyeong Province. (Figure 1) It was the second nuclear detonation under the leadership of Kim Jong Un. Unlike the past three tests, North Korea claimed it was

* Professor of International Law at Dongguk University - Seoul, Korea; President of YIJUN Institute of International Law. B.A. (U. Washington), M.P.A. (Seoul N. U.), LL.M. (Leiden), Dr.iur. (Erasmus). ORCID: http://orcid.org/00000001-5640-490X. This work was supported by the research program of Dongguk University. The views reflected in this article are his own. Readers' comments are cordially welcome. The author may be contacted at: grotian@hotmail. com / Address: 562 Gwangnaruro, Kwangiin-gu \#201, Seoul 05033 Korea. DOI: http://dx.doi.org/10.14330/jeail.2016.9.1.11 
a 'hydrogen bomb.' ${ }^{1}$ This is, however, speculated to in fact be a kind of boosted 'fission' weapon by nations including the US, China, and South Korea; it is due to the consequent 5.1 magnitude earthquake ${ }^{2}$ with its epicenter at the nuclear test site, being notably similar to the earthquake size that was accompanied by the 2013 nuclear test by North Korea. ${ }^{3}$

Figure 1: The Punggye-ri Nuclear Test Site ${ }^{4}$

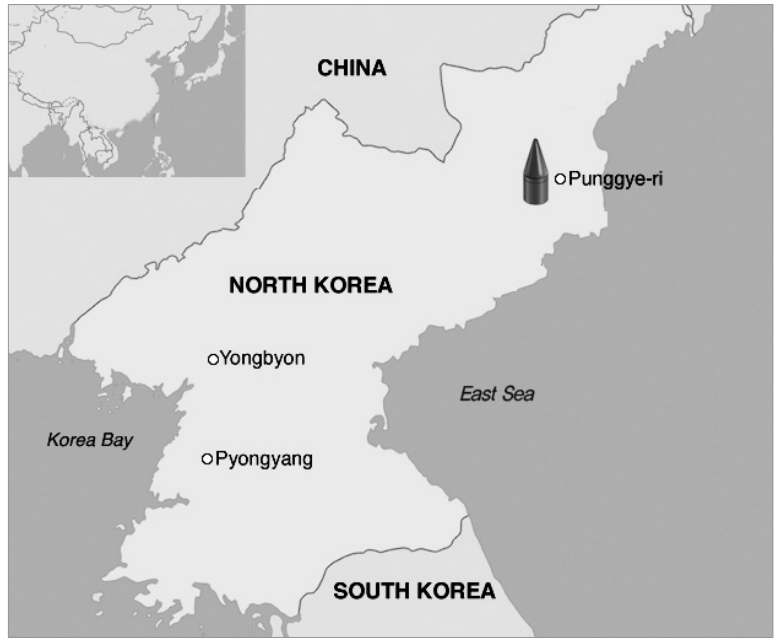

Source: Compiled by the author

North Korea's nuclear test was instantly responded to with severe criticism by the international community. The US, Japan, and South Korea referred to it as a serious violation of international law, and the UN Security Council adopted a resolution towards complete nuclear non-proliferation. ${ }^{5}$ China and Russia also condemned the

1 See North Korea says it tested hydrogen bomb, NK NEws, Jan. 6, 2016, available at http://www.nknews.org/2016/01/ north-korea-says-it-tested-hydrogen-bomb (last visited on May 3, 2016).

2 J. McCurry \& M. Safi, North Korea claims successful hydrogen bomb test in "self-defense against US, " GuARDIAN, Jan. 6, 2016, available at http://www.theguardian.com/world/2016/jan/06/north-korean-nuclear-test-suspected-as-artificialearthquake-detected (China said the earthquake was 4.9 magnitude). See also China Earthquake Data Center <available only in Chinese>, available at $\mathrm{http} / /$ data.earthquake.cn/datashare/datashare_details_subao.jsp?id=CC20160106094443 (all last visited on May 3, 2016).

3 USGS, M5.1 Nuclear Explosion - 24km ENE of Sungjibaegam, North Korea, available at http://earthquake.usgs.gov/ earthquakes/eventpage/usc000f5t0 (last visited on May 3, 2016).

4 See North Korea's nuclear programme: How advanced is it?, BBC NEws, Feb. 10, 2016, available at http://www.bbc. com/news/world-asia-pacific-11813699 (last visited on May 12, 2016).

5 See North Korea nuclear: State claims first hydrogen bomb test, BBC News, Jan. 6, 2016, available at http://www.bbc. com/news/world-asia-35240012 (last visited on Apr. 12, 2016) 
North Korea's actions. ${ }^{6}$ To make matters worse, however, North Korea launched a long-range rocket on February 7, 2016, named Kwangmyongsong-4 (광명성) at the Tongchang-ri satellite launch site near its northwestern border with China. ${ }^{7}$ Despite prior notification to the International Maritime Organization of the launch of an earth observation satellite, the international community severely reprimanded North Korea of its rocket launch, which is believed to be part of its developing an intercontinental ballistic missile capable of delivering a nuclear bomb. ${ }^{8}$ It was another violation of a series of Security Council resolutions prohibiting North Korea from developing ballistic-missile technologies.

\section{Resolution $\mathbf{2 2 7 0}$}

North Korea's nuclear test and succeeding rocket launch brought a strong response from the UN. On March 2, 2016, the Security Council unanimously passed Resolution 2270 , imposing strong sanctions against North Korea. ${ }^{10}$ The resolution was approved by the members of the Council after nearly two months' painstaking negotiations after the January 6 nuclear test, a time period longer than the average number of days for previous resolutions.

The Security Council condemned North Korea's nuclear test as well as the rocket launch that used ballistic missile technology as being "in violation and flagrant disregard of the relevant resolutions, thereby constituting a challenge to the Treaty on Non-Proliferation of Nuclear Weapons ("NPT") and to peace and stability in the region and beyond." 11

6 See N Korean nuclear test condemned as intolerable provocation, ChANnel NewsAsiA, Jan. 6, 2016, available at http:// www.channelnewsasia.com/news/asiapacific/n-korean-nuclear-test/2404166.html; O. Gertcyk, Russia condemns North Korea's 'nuclear bomb test', a 'threat to national security,' Siberian Times, Jan. 6, 2016, available at http:// siberiantimes.com/other/others/news/n0545-russia-condemns-north-koreas-nuclear-bomb-test-a-threat-to-nationalsecurity (all last visited on Apr. 12, 2016).

7 See North Korea fires long-range rocket despite warnings, BBC News, Feb. 7, 2016, available at http://www.bbc.com/ news/world-asia-35515207 (last visited on May 3, 2016).

8 Sang-hun Choe, North Korea Launches Rocket Seen as Cover for a Missile Test, N.Y. Times, Feb. 6, 2016, available at http://www.nytimes.com/2016/02/07/world/asia/north-korea-moves-up-rocket-launching-plan.html (last visited on May 3, 2016).

$9 \quad I d$.

10 Min-sik Yoon, U.N. passes toughest sanctions against North Korea, Korea Herald, Mar. 2, 2016, available at http:// www.koreaherald.com/view.php?ud=20160302000075 (last visited on May 3, 2016).

11 UN, Security Council Imposes Fresh Sanctions on Democratic People's Republic of Korea, Unanimously Adopting Resolution 2270 (2016), SC 7638th Mtg. Coverage, UN Doc. SC/12267, available at http://www.un.org/press/en/2016/ 
Resolution 2270 imposes an embargo against North Korea by means of earth, air, and sea, on exports of resources and finances to prevent the flow of money. It even prohibits exporting minerals such as coal and iron ore, which constitute its main source of income. ${ }^{12}$ However, the export of coal is exempt if the income derived from it is used for the survival of the North Korean population. ${ }^{13}$ As a financial sanction, meanwhile, the UN Member States must close and cease financial activities with all North Korean banks within 90 days. ${ }^{14}$ The sanction also extends to the prohibition of opening new branches and representative offices of North Korean banks. ${ }^{15}$ Resolution 2270 extends tougher measures than any previous ones, including Resolutions 1718 (2006), 1874 (2009), 2087 (2013), and 2094 (2013).

Table 1: North Korea's Nuclear Tests and the UN Security Council Resolutions ${ }^{16}$

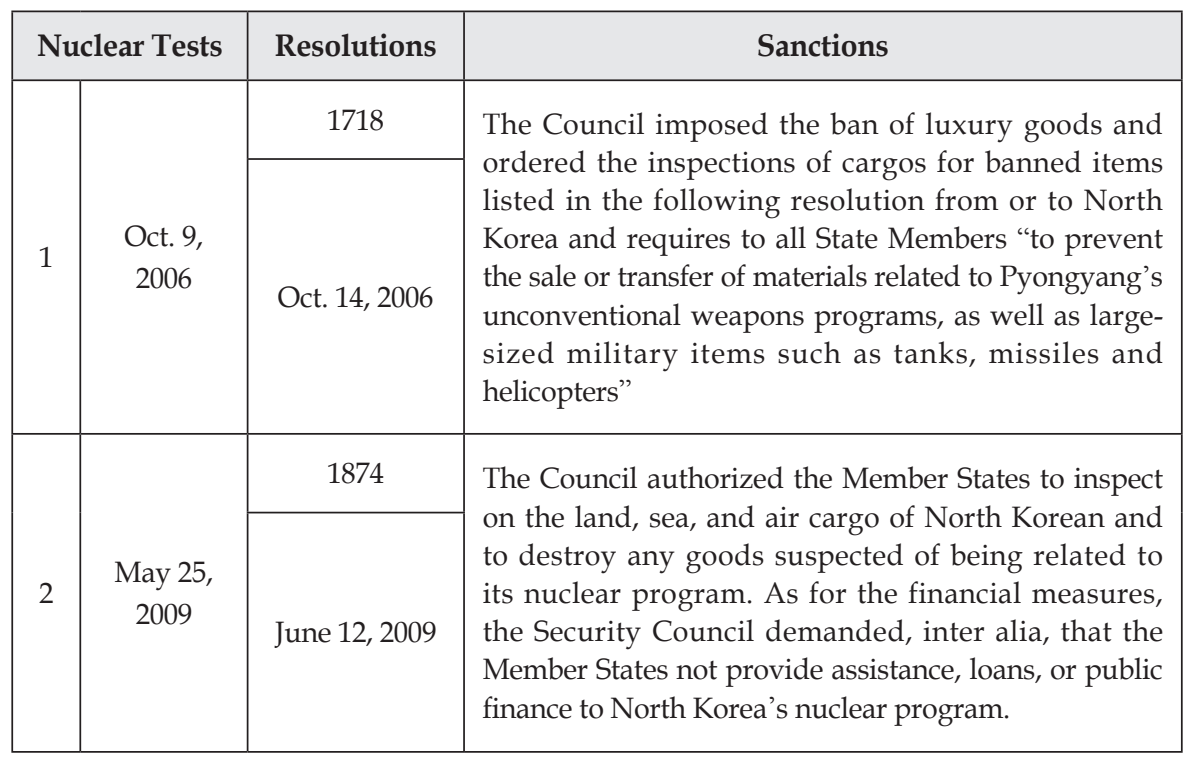

sc12267.doc.htm (last visited on May 3, 2016).

12 S.C. Res. 2270, U.N. Doc. S/RES/2270 (Mar. 2, 2016) at 9 29, available at http://www.un.org/en/ga/search/view_doc. asp?symbol=S/RES/2270(2016) (last visited on May 3, 2016)

13 Id. 948.

14 Id. 133.

15 Id. 134.

16 See The UN Security Council Resolution website, available at http://www.un.org/en/sc/documents/resolutions (last visited on May 3, 2016). 


\begin{tabular}{|c|c|c|c|}
\hline \multirow[b]{2}{*}{3} & & 2094 & \multirow{2}{*}{$\begin{array}{l}\text { The Council obliged the Member States to freeze } \\
\text { financial transactions and bulk cash transfers involved } \\
\text { in North Korea's illicit activities. Furthermore, the } \\
\text { interdiction and inspection of all suspicious ships and } \\
\text { cargos also became mandatory for the Member States }\end{array}$} \\
\hline & $\begin{array}{c}\text { Feb. 12, } \\
2013\end{array}$ & Mar. 7, 2013 & \\
\hline & & 2270 & \multirow{2}{*}{$\begin{array}{l}\text { The Council imposed on North Korea an earth, air, and } \\
\text { sea embargo on exports of resources and finances to } \\
\text { prevent the flow of money, including the prohibition } \\
\text { to export minerals such as coal and iron ore, which } \\
\text { constitute its main source of income. Within } 90 \text { days, } \\
\text { UN's Member States must close and cease financial } \\
\text { activities with all North Korean banks. }\end{array}$} \\
\hline 4 & $\begin{array}{c}\text { Jan. 6, } \\
2016\end{array}$ & $\begin{array}{c}\text { Mar. 2, } \\
2016\end{array}$ & \\
\hline
\end{tabular}

Source: Compiled by the author

\section{Impasse}

North Korea's nuclear weapons development program is not a recent project. It traces back to 1993, when North Korea refused the IAEA's special inspection of the two sites that were suspected to be storing nuclear waste from plutonium production under the Safeguard Agreement and declared withdrawal from the NPT. ${ }^{17}$ The UN Security Council then adopted Resolution 825 against North Korea in response to its threats to the global nuclear security system. The hostility between North Korea and the US was escalating to that of an armed conflict, but was peacefully resolved with the Geneva Agreed Framework in October 1994. In this Agreed Framework, the US promised to provide Light Water Reactors ("LWRs") to North Korea by 2003 and further open negotiations for the establishment of a peaceful diplomatic relationship. ${ }^{18}$ Responding to these promises, North Korea unloaded 8000 spent fuel rods by June 1995 and, in October 1998, announced that it would not export missiles in return for the US financial support of USD 3 billion for three years. ${ }^{19}$ As North Korea opened its suspicious underground facilities at Kumchang-ri to the

17 Eric Yong Joong Lee, The Complete Denuclearization of the Korean Peninsula: Some Considerations under International Law, 9 CHINESE J. INT'L L. 803 (2010).

18 IAEA, Agreed Framework of 21 October 1994 between The United States of America and the Democratic People's Republic of Korea, INFCIRC/457, Nov.2 (1994), available at https://web.archive.org/web/20031217175315/http:// www.iaea.org/Publications/Documents/Infcircs/Others/infcirc457.pdf (last visited on Apr. 12, 2016).

19 Supra note 17 , at 804. 
US inspection team, the US promised to lift economic sanctions and provide food support to North Korea. ${ }^{20}$ The Geneva Agreed Framework seemed to establish a highway to a nuclear-free Korean Peninsula. Such a cooperative mood, however, drastically changed with the hostile policies of the US towards North Korea during the Bush administration. When President Bush suddenly designated North Korea part of an "axis of evil" with Iran and Iraq, ${ }^{21}$ North Korea regarded it as an actual declaration of war and acknowledged its nuclear weapons development program in October 2002. ${ }^{22}$

In April 2003, the US and North Korea resumed contact to ease the standoff at the trilateral talks held in Beijing on April 23, 2003. Both sides reached an accord that this crisis should be handled in a more peaceful and systematic manner among the nations concerned. Such an envisaged framework was finally realized in the form of the Six-Party Talks. The six nations, including China, the US, Russia, Japan, and the two Koreas, got together in Beijing on August 27, 2003, discussed the means to resolve the pressing issue of North Korea's nuclear weapons program. ${ }^{23}$ The fourth round of the Six Party Talks finally delivered a Joint Statement on September 19, 2005 by which North Korea committed to abandoning all nuclear weapons and existing nuclear programs and returning back to the NPT and to IAEA safeguards. ${ }^{24}$

The September 19 Joint Statement was an iconic turning point toward a peaceful settlement of the North Korean nuclear dispute. However, it was not implemented because North Korea strongly protested against the US freezing its secret fund in the Banco Delta Asia Bank of Macao. ${ }^{25}$ Responding to this financial block, on October 9, 2006, North Korea carried out its first underground nuclear test at the Punggye-

20 Id. For details on the US-North Korea Berlin high-ranking meeting in September 1999, see Chronology of US-North Korean Nuclear and Missile Diplomacy, available at https://www.armscontrol.org/factsheets/dprkchron (last visited on Apr. 18, 2016).

21 State of the Union Address on 29 January 2002, available at http://georgewbush-whitehouse.archives.gov/news/ releases/2002/01/20020129-11.html (last visited on May 3, 2016).

22 Eric Yong Joong Lee, The Six-Party Talks and the North Korean Nuclear Dispute Resolution under the IAEA Safeguards Regime, 5 Asian-PACIFIC L. \& Pol'y J. 114 (2004).

23 Council on Foreign Relations, The Six Party Talks on North Korea's Nuclear Problem, available at http://www.cfr.org/ proliferation/six-party-talks-north-koreas-nuclear-program/p13593 (last visited on May 3, 2016).

24 US Dept. of State Diplomacy in Action, Six-Party Talks, Beijing, China: Joint Statement of the Fourth Round of the Six-Party Talks Beijing 19 September 2005, available at http://www.state.gov/p/eap/regional/c15455.htm (last visited on May 3, 2016).

25 US Dept. of the Treasury, Treasury Designates Banco Delta Asia as Primary Money Laundering Concern under USA PATRIOT Act, Sept. 15, 2005, available at https://www.treasury.gov/press-center/press-releases/Pages/js2720.aspx. For details, see D. Lague \& D. Greenlees, Squeeze on Banco Delta Asia hit North Korea where it hurt - Asia - Pacific - International Herald Tribune, N.Y. Times, Jan. 18, 2007, available at http://www.nytimes.com/2007/01/18/world/ asia/18iht-north.4255039.html (all last visited on May 3, 2016) 
ri Nuclear Test Site; ${ }^{26}$ this was followed by Security Council Resolution $1718 .^{27}$ The Council demanded, inter alia, that North Korea "not conduct any further nuclear test or launch of a ballistic missile" as well as "suspend all activities related to its ballistic missile program" and "abandon all nuclear weapons and existing nuclear programs in a complete, verifiable and irreversible manner." 28 The Council also asked its Member States to freeze their assets and place a travel ban on people and businesses involved in North Korea's nuclear program, further ordering North Korea to return to the Six-Party Talks 'without precondition. ${ }^{, 29}$

Things, however, took a turn for the worse when North Korea carried out its second underground nuclear test on May 25, 2009, with its yield estimated at 2.35 kilotons. ${ }^{30}$ In response, on June 12, 2009, the Security Council unanimously adopted Resolution 1874, imposing a ban on all arms transfers from and to North Korea. ${ }^{31}$ The Council authorized Member States to inspect the land, sea, and air cargo of North Korean and destroy any goods suspected of being related to its nuclear program. As for financial measures, the Security Council demanded, inter alia, that Member States not provide assistance, loans, or public financial to North Korea's nuclear program. ${ }^{32}$ In spite of the Security Council's strong sanctions, North Korea carried out its third underground nuclear test on February 12, 2013. ${ }^{33}$ On March 7, 2013, the Security Council unanimously adopted Resolution 2094 against the nuclear test. This resolution instructed North Korea to abandon all nuclear weapons and existing nuclear programmes, in a "complete, verifiable and irreversible" manner and immediately cease all related activities." 34 The resolution also made some

26 D. Sanger, North Koreans Say They Tested Nuclear Device, N.Y. TimEs, available at http://www.nytimes. com/2006/10/09/world/asia/09korea.html? r=1 (last visited on May 3, 2016).

27 S.C. Res. 1718, U.N. Doc. S/RES/1718 (Oct. 14, 2006), available at http://www.un.org/en/ga/search/view_doc. asp?symbol=S/RES/1718(2006) (last visited on May 3, 2016).

$28 I d$. $\mid$ ๆ $2,5, \& 6$

29 See UN slaps sanctions on North Korea, BBC NEws, available at http://news.bbc.co.uk/2/hi/asia-pacific/6051704.stm (last visited on May 3, 2016).

30 Feng Zhao Lia, et al. Yield Estimation of the 25 May 2009 North Korean Nuclear Explosion, Seismological Society OF AMERICA BuLL., available at http://www.bssaonline.org/content/102/2/467.abstract?sid=7c769220-2dfc-45b2-96d7$73 \mathrm{fef} 9 \mathrm{aa} 8 \mathrm{~d} 48$ (last visited on May 3, 2016).

31 Bureau of Public Affairs, Office of the Spokesman Washington, DC, North Korea Sanctions: Resolution 1718 versus Resolution 1874, available at http://www.state.gov/r/pa/prs/ps/2009/06a/124709.htm (last visited on May 3, 2016).

32 S.C. Res. 1874, U.N. Doc. S/RES/1874 (June 12, 2009), ๆ 20, available at http://www.un.org/en/ga/search/view_doc. asp?symbol=S/RES/1874(2009) (last visited on May 3, 2016).

33 See Essai nucléaire en Corée du Nord: Pour la Maison Blanche Pyongyang n'a pas la bombe H, 20 Minutes, available at http://www.20minutes.fr/monde/1760331-20160106-direct-essai-nucleaire-coree-nord-france-condamne-fermement (last visited on May 3, 2016).

34 S.C. Res. 2094, ๆ 5, U.N. Doc. S/RES/2094 (March 7, 2013), available at http://www.un.org/en/ga/search/view_doc. asp?symbol=S/RES/2094(2013) (last visited on May 3, 2016). 
existing sanctions mandatory. In fact, it obligated Member States to freeze financial transactions and bulk cash transfers involved in North Korea's illicit activities. Furthermore, interdiction and inspection of all suspicious ships and cargos also became mandatory. ${ }^{35}$ Pyongyang accused the US of triggering a nuclear war and threatened to denounce the armistice agreement that ceased fire of the Korean War in $1953 .^{36}$ Both sides lost the chance at an exit from the nuclear impasse, finally leading to the fourth nuclear test in January 2016.

\section{Frustrations}

\section{A. Rule of Law}

The North Korean nuclear weapons development has been one of the most serious issues faced by the international community since the early 1990s. For the past ten years, in particular, the UN Security Council has consistently delivered strong economic sanctions against North Korea in response to each of its nuclear tests; however, they did not successfully stop the nuclear crisis. Such frustrations are especially due to critical legal loopholes in the NPT. The core purpose of the NPT is to prevent the spread of nuclear weapons and weapons technology, to promote cooperation in the peaceful uses of nuclear energy, and to further achieve nuclear disarmament and general and complete disarmament. ${ }^{37}$ However, the NPT is distorted by its inherent double standard; it is composed of both the five "recognized nuclear weapon States," who are legitimately entitled to have nuclear weapons under the Treaty, and the 185 "other non-nuclear weapon States" who have agreed never to acquire or develop nuclear weapons. This unbalanced bargain has been maintained mainly through two legal and policy initiatives: (1) the "nuclear umbrella,' which "refers to a guarantee by a nuclear weapons state to defend a nonnuclear allied state"38 and (2) 'nuclear disarmament,' which refers to "reducing and

35 Victor Cha \& Ellen Kim, UN Security Council Passes New Resolution 2094 on North Korea, Center for Strategic and International Studies, available at http://csis.org/publication/un-security-council-passes-new-resolution-2094-northkorea (last visited on May 3, 2016).

36 See L'ONU impose de nouvelles sanctions à la Corée du Nord, LE Monde, available at http://www.lemonde.fr/asiepacifique/article/2013/03/07/l-onu-impose-de-nouvelles-sanctions-a-la-coree-du-nord_1844627_3216.html (last visited on May 3, 2016).

37 UNODA, Treaty on the Non-Proliferation of Nuclear Weapons, available at http://www.un.org/disarmament/WMD/ Nuclear/NPT.shtml (last visited on May 3, 2016).

38 A. Persbo, Verification and Nuclear Disarmament, in Global Nuclear Disarmament: Strategic, Political and 
eliminating nuclear weapons."39 The nuclear umbrella system, however, has not been fully successful on the Korean Peninsula, because nuclear defense levels of Russia, China, and North Korea do not compare to the finesse of that of the US and South Korea. The nuclear disarmament system is, thus, seriously biased. In order to realize global nuclear disarmament, nuclear-weapon States ("NWS") should gradually eliminate their nuclear arms under Article VI of the NPT. Despite global denuclearization negotiations, ${ }^{40}$ however, both the US and Russia each currently deploy nearly a reported 2000 operational nuclear heads all over the globe for their strategic interests. ${ }^{41}$ They are even incurring a great deal of expenditure for the development and deployment of nuclear weapons in the future. ${ }^{42}$ North Korea would severely criticize this hypocrisy and thereby justify its own nuclear weapons development program. ${ }^{43}$

Another serious problem regarding the NPT is that non-signatories who are believed to possess nuclear weapons - India, Pakistan and Israel - have not been sanctioned for their positions opting out of the NPT. Considering that North Korea was severely sanctioned by Security Council Resolution 825 (1993) just for declaring its withdrawal from the Treaty, these three countries are treated more favorably than North Korea, which cried 'unfairness' on the part of the international community. Actually, Article X of the NPT grants each party the right to withdraw from the Treaty when "extraordinary events, related to the subject matter of this Treaty, have jeopardized the supreme interests of its country" notice. Such an easy withdrawal route would attract more parties without much introspection. This provision was presumed to be adopted in order to substitute weak normal powers of the NPT with global extension of parties.

Regional Perspectives, ch. 6, n. 4 (N. Hynek \& M. Smetana eds., 2016).

39 For details on the definition of nuclear disarmament, see J. Doyle, Why Eliminate Nuclear Weapons?, 55 IISS Survival: Global Politics and Strategy (2013), available at https:/www.iiss.org/en/publications/survival/sections/ 2013-94b0/survival--global-politics-and-strategy-february-march-2013-3db7/55-1-02-doyle-a88b(last visited on May 3, 2016).

40 For detail, see Strategic Arms Limitation Treaty, available at https://history.state.gov/milestones/1969-1976/salt; Strategic Arms Reduction Treaty, available at http://www.nti.org/learn/treaties-and-regimes/treaties-between-unitedstates-america-and-union-soviet-socialist-republics-strategic-offensive-reductions-start-i-start-ii (all last visited on May 3, 2016).

41 See The Nuclear Threat Initiative, available at http://www.nti.org/learn/countries/russia/nuclear (last visited on May 3, 2016).

42 See The Costs of U.S. Nuclear Weapons, available at http://www.nti.org/analysis/articles/costs-us-nuclear-weapons (last visited on May 3, 2016).

43 See KCNA detailed report on circumstances of DPRK's withdrawal from NPT, available at http://caledavis.com/ Sources/2003/KCNADetailedReportOnNPTWithdrawal.pdf (last visited on Apr. 30, 2016).

44 NPT art. V(1). [Emphasis added] 
Today, 'nonproliferation' is aligned with 'nuclear terrorism. ${ }^{45}$ It is, however, unequal to the North Korean nuclear test because 'terrorism' is mainly associated with Non-State Actors ("NSAs"). ${ }^{46}$ North Korea does not qualify as an NSA, but a UN Member State out of the purview of the NPT. It can effectively bind North Korea only when each NWS is respecting those rules and substantially reducing its nuclear weapons. Without the sincere devotion of each NWS to a nuclear free world, North Korea's recalcitrant behavior is likely to continue.

\section{B. Governance}

North Korea has been trying to develop nuclear weapons in order to overcome its regime crisis in the post-Cold War era. Following the destruction of the former Soviet Union and other socialist allies in the 1990s, as well as China's balanced approach toward the two Koreas, North Korean leadership was getting concerned about its physical security and decided to go nuclear.

The nuclear weapons development program lies in a critical point of contention in regional as well as world politics. It was a kind of 'trump card' for the late Kim Jong Il to defend his regime against the severe crises from both the inside and outside, and thereby successfully shift power to his son, Kim Jong Un. Currently, the nuclear weapons program is not only an efficient measure for North Korea to compensate for its inferiority in its conventional arms race with South Korea, ${ }^{47}$ but also a leverage for negotiations with the US and China. What if North Korea had abolished its nuclear weapons program in its early stage? Kim would have supposed his regime could not be sustained. Iran and Libya were probably good lessons for Kim Jong Un. This is precisely why North Korea desperately clings to its nuclear weapons program, despite the severe condemnation and isolation from the

45 US Dept. of State, The Threat of Nuclear Terrorism, Diplomacy in Action, Sept. 18, 2015, available at http://www. state.gov/t/us/2015/247083.htm. For details, see Global Initiative to Combat Nuclear Terrorism, available at http:// www.gicnt.org (all last visited on Apr. 18, 2016)

46 U Schneckener, Fragile statehood, armed non-state actors and security governance, in PRIVATE ACTORS AND Security Governance 24-38 (A. Bryden \& M. Caparini eds., 2006), available at https://scholar.google.co.kr/sc holar? $\mathrm{q}=$ Fragile + Statehood $\% 2 \mathrm{c}+$ Armed + Non-State + Actors + and + Security + Governance $+\& b t n G=\&$ hl $=$ en $\&$ as $\mathrm{sdt}=0 \% 2 \mathrm{c} 5 \&$ as_vis=1 See also M. O'Connell, Enhancing the Status of Non-State Actors Through a Global War on Terror?, 43 Colum J. Transnat'L L. 436-58 (2005), available at http://scholarship.law.nd.edu/cgi/viewcontent. cgi?article $=1087 \&$ context=law_faculty_scholarship (all last visited on Apr. 30, 2016).

47 D. Blair, North Korea $v$ South Korea: How the countries' armed forces compare, TelegraPH, Sept. 15, 2015, available at http://www.telegraph.co.uk/news/worldnews/asia/northkorea/11603665/North-Korea-v-South-Korea-How-thecountries-armed-forces-compare.html. See also G. McCafferty, Anniversary parade provides rare glimpse into North Korea's military might, CNN, Oct. 10, 2015, available at http://edition.cnn.com/2015/10/09/asia/north-korea-militarymight (all last visited on Apr. 30, 2016). 
international community.

Up until 2008, North Korea's denuclearization question had been discussed via the Six-Party Talks. As mentioned above, the talks were triggered by the second nuclear crisis, in which North Korea re-declared withdrawal from the NPT on January 10, 2003, against the "tailored containment policy" of the US. ${ }^{48}$ In spite of the seemingly successful result with the September 19 Joint Statement, ${ }^{49}$ the Six-Party Talks are not working anymore because of North Korea's nuclear and missile (rocket) tests. No more talks have been held since late 2008 .

Table 2: The Six-Party Talks against North Korea's Nuclear Weapons Development ${ }^{50}$

\begin{tabular}{|c|c|c|l|}
\hline Round & \multicolumn{2}{|c|}{ Period } & \multicolumn{1}{c|}{ Results } \\
\hline 1st & Aug. 27-Aug 29,2003 & To agree on a further round of talks \\
\hline 2nd & Feb. 25 - Feb. 28, 2004 & $\begin{array}{l}\text { To announce the denuclearization of the Korean } \\
\text { Peninsula; peaceful coexistence of participating } \\
\text { States; the use of mutually coordinated measures to } \\
\text { resolve crises }\end{array}$ \\
\hline 3rd & June 23-June 26, 2004 & $\begin{array}{l}\text { To stress denuclearizing the Korean Peninsula } \\
\text { within the specific scope and time, interval, and } \\
\text { method of verification. }\end{array}$ \\
\hline 4th & Phase 1 & $\begin{array}{c}\text { July 26- } \\
\text { Aug. 7, 2005 }\end{array}$ & $\begin{array}{l}\text { Joint Statement (Sept. 19): North Korea to agree to } \\
\text { abandon all nuclear weapons and nuclear programs } \\
\text { and return to the NPT as soon as possible. The US } \\
\text { and North Korea will work to normalize ties, respect } \\
\text { each other's sovereignty, and exist peacefully } \\
\text { together. }\end{array}$ \\
\cline { 2 - 4 } & Phase 2 & $\begin{array}{c}\text { Sept. 13 - 19, 2005 } \\
\text { Sept. }\end{array}$ \\
\hline
\end{tabular}

48 Supra note 22, at 114. See also M. Gordon, U.S. Readies Plan to Raise Pressure on North Koreans, Dec. 29, 2002, N.Y. TIMES, available at http://www.nytimes.com/2002/12/29/international/asia/29KORE.html?pagewanted=all (last visited on May 3, 2016).

49 US Dept. of State, Joint Statement of the Fourth Round of the Six-Party Talks, Beijing 19 September 2005, Diplomacy in Action, available at http://www.state.gov/p/eap/regional/c15455.htm (last visited on May 3, 2016).

50 Xiaodon Liang, The Six-Party Talks at a Glance, Arms Control Association, available at https://www.armscontrol.org/ factsheets/6partytalks (last visited on May 3, 2016). 


\begin{tabular}{|c|c|c|c|}
\hline \multirow{3}{*}{5 th } & Phase 1 & $\begin{array}{c}\text { Nov. } 9- \\
\text { Nov. 11, } 2005\end{array}$ & \multirow{3}{*}{$\begin{array}{l}\text { Joint Statement (Feb. 13): North Korea will shut } \\
\text { down and seal the Yongbyon nuclear facility and } \\
\text { invite again IAEA personnel to conduct all necessary } \\
\text { monitoring and verifications. In return, the other five } \\
\text { parties in the six-party talks will provide emergency } \\
\text { energy assistance to North Korea in the initial phase } \\
\text { of } 50,000 \text { tons of heavy fuel oil, to commence within } \\
60 \text { days. }\end{array}$} \\
\hline & Phase 2 & $\begin{array}{c}\text { Dec. } 18- \\
\text { Dec. } 22,2006\end{array}$ & \\
\hline & Phase 3 & $\begin{array}{c}\text { Feb. } 8 \text { - } \\
\text { Feb. 13, } 2007\end{array}$ & \\
\hline \multirow[b]{2}{*}{ 6th } & Phase 1 & $\begin{array}{c}\text { July } 18- \\
\text { July 20, } 2007\end{array}$ & \multirow{2}{*}{$\begin{array}{l}\text { Joint Statement (July 20): The Six Parties reconfirmed } \\
\text { their commitment to the past Joint Statement of } \\
\text { September 19, } 2005 \text { and February 13, 2007. North } \\
\text { Korea confirmed its agreement to disclose all nuclear } \\
\text { programs and disable all facilities related to its } \\
\text { nuclear programs. }\end{array}$} \\
\hline & Phase 2 & $\begin{array}{c}\text { Sept. } 27 \text { - } \\
\text { Sept. } 302007\end{array}$ & \\
\hline
\end{tabular}

Source: Compiled by the author

The current deadlock is caused by the failure of coordinating strategic interests among the key actors of the Six-Party Talks. In particular, the US and North Korea are seeking denuclearization from diametrically opposite sides. North Korea claims that as nuclear weapons program is a self-defense measure from the potential (nuclear) attack of the US and South Korea, their security should be guaranteed first by the US before denuclearization. ${ }^{51}$ North Korea requires the US to conclude the 'peace treaty,' which finalizes the current 'armistice' and to lift the sanctions for economic recovery. ${ }^{52}$ Such positions were well reflected in the provisions of the Geneva Agreed Framework and the September 19 Joint Statement. The American mainstream circle, however, has maintained a totally different stance. They might want fundamental 'regime change.' Especially, 'Neoconservatives'under the Bush administration pressed North Korea to the tip of the cliff by declaring the then Kim Jong Il regime an "axis of evil" ${ }^{\text {"53 }}$ and an "outpost of tyranny." 54 Such a hostile standoff provoked North Korea to deny even a tiny chance of consensus for denuclearization from the Six-Party Talks and gave it the final push toward nuclear and missile tests. Because of this vicious circle, the only negotiation forum available

51 Supra note 17 , at 800

52 See North Korea says peace treaty, halt to exercises, would end nuclear tests, REUTERS, Jan. 16, 2016, available at http:/www.reuters.com/article/us-northkorea-nuclear-usa-idUSKCN0UT201 (last visited on May 3, 2016).

53 See 2002 State of Union Address, The White House, available at http:/georgewbush-whitehouse.archives.gov/news/ releases/2002/01/20020129-11.html (last visited on May 3, 2016).

54 See Rice names 'outposts of tyranny,' BBC News, Jan. 19, 2005, available at http://news.bbc.co.uk/2/hi/americas/ 4186241.stm (last visited on May 3, 2016). 
has not been open for the past eight years. The more the US and South Korea press North Korea, the more North Korea resists with nuclear tests.

\section{Two-Track Approach}

As mentioned above, Resolution 2270 releases tougher sanction measures than any other resolutions adopted by the Security Council concerning nuclear tests. It contains "further significant measures," which were mentioned in Resolution 2094 (2013). Resolution 2270 was followed by the US Congress' "North Korea Sanctions and Policy Enhancement Act of 2016" provision (February 10) as well as South Korea's closing of the Kaesong Industrial Complex, which was a symbol of inter-Korean economic cooperation (February 11). ${ }^{56}$ Both the US and South Korea expect North Korea to ultimately abandon its nuclear weapons program. China, however, has the key to effectively implementing the resolution. This is because unprecedentedly tough sanctions could be adopted as a compromise between the US and China. Chinese Foreign Minister Wang Yi said: "Sanctions are necessary, and maintaining stability is the pressing priority, and only negotiations could provide a fundamental solution 制裁是必要手段, 维稳是当务 之急, 谈判是根本之道. ${ }^{, 57}$ In this sense, China is willing to defend its strategic interest in this region by sustaining the political status quo of North Korea's Kim Jong Un regime. ${ }^{58}$ It would be, however, inconsistent with the Obama administration's "Pivot to Asia"59 doctrine for maintaining American hegemony in the Asia-Pacific region. Their standoff could seriously exacerbate the North Korean nuclear crisis.

The best option to break such ongoing nuclear deadlock will be the "TwoTrack Approach,” which conceives both 'peacemaking' and 'denuclearization'

55 See H.R.757 - North Korea Sanctions and Policy Enhancement Act of 2016, 114th Congress (2015-2016), available at https://www.congress.gov/bill/114th-congress/house-bill/757 (last visited on May 3, 2016).

56 J. McCurry, Seoul shuts down joint North-South Korea industrial complex, GuARDiAn, Feb. 10, 2016, available at http:/www.theguardian.com/world/2016/feb/10/seoul-shuts-down-joint-north-south-korea-industrial-complex-kaesong (last visited on May 3, 2016).

57 Yunbi Zhang, Two Sessions: 'Flexibility vital' to solve nuclear issue, CHINA DAILY, Mar. 9, 2016, available at http:// iosnews.chinadaily.com.cn/newsdata/news//201603/09/379228/article.html (last visited on Apr. 11, 2016).

58 See China underscores equal implementation of UN resolution on DPRK, CHINA DAILY, Mar. 7, 2016, available at http://www.chinadaily.com.cn/world/2016-03/07/content_23774260.htm (last visited on May 3, 2016).

59 Eric Yong Joong Lee, Trans-Pacific Partnership (TPP) as a US Strategic Alliance Initiative under the G2 System: Legal and Political Implications, 8 J. EAST AsIA \& INT'L L. 337-9 (2015), available at http://yijuninstitute.blogspot. $\mathrm{kr} / 2015 / 12 /$ trans-pacific-partnership-tpp-as-us.html (last visited on May 3, 2016). 
simultaneously. It is a more proactive initiative developed from "a comprehensive and integrated approach" of the William Perry Report. ${ }^{60}$ Both the Geneva Agreed Framework and the September 19 Joint Statement refer to a peace regime based on mutual trust between the US and North Korea. Therefore, a peace treaty should be the other important agenda item for denuclearization negotiation. A stable peace regime will be a basis for a nuclear-free Korean Peninsula. Such a new approach will provide ample space to discuss the nuclear crisis in a more peaceful setting.

As an acting plan for peace regime building, the nuclear weapons free zone in Northeast Asia ("NEA-NWFZ") should be suggested. It is a fair and reasonable way to bring North Korea back to the contemporary nuclear deterrence system. The NWFZ would mean "a specified region in which countries commit themselves not to manufacture, acquire, test or possess nuclear weapons." ${ }^{, 61}$ It is also defined by the UN General Assembly as:

Any zone, recognized as such by the General Assembly of the United Nations, which any group of States, in the free exercise of their sovereignty, has established by virtue of a treaty or convention whereby: (a) The statute of total absence of nuclear weapons to which the zone shall be subject, including the procedure for the delimitation of the zone, is defined; (b) An international system of verification and control is established to guarantee compliance with the obligations deriving from that statute. ${ }^{62}$

NWFZ is closely associated with core values of the NPT for nuclear arms control. NPT also provides the right for any group of States to conclude regional treaties in order to assure a total absence of nuclear weapons in their respective areas. ${ }^{63}$ According to this rule, as of today, five regional NWFZs are successfully maintaining nuclear free regions. ${ }^{64}$

The NEA-NWFZ would include the Korean Peninsula, three prefectures of northeastern mainland China, Japan, and Far-East Russia. In this geographical scope, the six countries and the UN can mutually guarantee not to manufacture, acquire,

W. Perry, Review of United States Policy towards North Korea: Findings and Recommendations, Unclassified Report, Oct. 12, 1999, available at http://belfercenter.hks.harvard.edu/files/1997\%20NKPR.pdf (last visited on May 3, 2016).

61 Arms Control Association, Nuclear-Weapon-Free Zone at a Glance, Fact Sheets \& Briefs, available at https://www. armscontrol.org/factsheets/nwfz (last visited on May 3, 2016).

62 G.A. Res. 3472/B(XXX), U.N. Doc. A/10027/Add.1 (Dec.11, 1975), available at http://www.un.org/disarmament/ HomePage/ODAPublications/DisarmamentStudySeries/PDF/A-10027-Add1.pdf. For details, see Nuclear-WeaponFree Zones, 1975 U.N.Y.B. at 8-10, available at http://www.unmultimedia.org/searchers/yearbook/search.jsp?q=1975 (all last visited on May 3, 2016).

63 NPT art. VII.

64 Supra note 17 , at $810-2$. 
test, accrue, or possess nuclear weapons. There is no objection from the US, China, or Russia. North Korea is also affirmative to this regional NWFZ. ${ }^{65}$ UN Secretary General Ban Ki-moon previously suggested the establishment of the NWFZ as one of the five proposals for nuclear disarmament. ${ }^{66}$ Such a collective certified framework for denuclearization would place North Korea back into the nonproliferation system.

The North Korean nuclear weapons development program must be abolished in a "comprehensive, verifiable and irrevocable" manner as soon as possible. Denuclearization of North Korea, however, is not pre-condition for the process, but the final result of all the negotiations. Technically, a sudden denuclearization is impossible. What is urgently needed is a nuclear free Korean Peninsula, not a fundamental regime change of North Korea. A freer and more open North Korea should be coming after painstaking course.

\section{Conclusion}

The fourth Washington Nuclear Security Summit adopted the Communique on April 1, 2016 (hereinafter, Washington Communiqué). The leaders agreed to strengthen "the nuclear security architecture at national, regional and global levels, including through broadened ratification and implementation of international legal instruments regarding nuclear security."

The Washington Communiqué is deeply concerned with North Korea's nuclear weapons development as a serious violation of international law and the global consensus for a nuclear secure world. In Washington, they have agreed to cooperate to ease nuclear tension. Nonetheless, North Korea is not expected to stop the nuclear weapons program because of the loopholes of the current NPT system and the distorted structure of regional politics, which can be understood as a 'Hostile Co-existence.'Both sides take advantage of this continuing pattern. Each side has been stimulating the other in order to expand its domestic and regional interests. The 2016 US-

65 U.N. Doc. S/23172 (Oct.28, 1991), available at http://www.un.org/en/ga/search/view_doc.asp?symbol=S/23172 (last visited on May 3, 2016).

66 UNODA, The United Nations and security in a nuclear-weapon-free world: The Secretary-General's five point proposal on nuclear disarmament, available at $\mathrm{http} / /$ www.un.org/disarmament/WMD/Nuclear/sg5point.shtml (last visited on May 3, 2016).

67 See Nuclear Security Summit 2016 Communiqué, The White House Office of the Press Secretary, Apr. 1, 2016, available at https://www.whitehouse.gov/the-press-office/2016/04/01/nuclear-security-summit-2016-communiqu\% C3\%A9 (last visited on May 3, 2016). 
South Korean Combined Forces Command's Key Resolve and Foal Eagle exercise ${ }^{68}$ showed a notable example of how both sides manipulated military tension suddenly escalating between them. This was the largest joint military drill ever conducted, focusing on so-called 'Operation 5015,' which calls for prompt retaliation after North Korean attacks or even a preemptive strike on the North's core military facilities and weapons as well as on its top leaders. ${ }^{69}$ North Korea responded to this grand military demonstration with a few short-range missile launches, an exposure of its nuclear weapons, and submarine-launched ballistic missile ("SLBM") launches. Some contents of 'Operation 5015' unofficially refers to 'decapitation' of North Korean leader Kim Jong Un. However, it might be a violation of contemporary international law prohibiting acts of aggression..$^{70}$

As just an economic sanction is less fearful than a regime collapse for the North Korean leadership, they would stop neither nuclear tests, nor the nuclear program. North Korea has repeatedly said that nuclear weapons are not bargaining chips. It is, however, a typical tactics for them to take initiative in the negotiations. A fundamental regime change in North Korea is not a feasible policy option for China, either, due to its deep interest in North Korea's geopolitical position as a bridgehead resisting American hegemonic domination of East Asia by way of such strategic initiatives as the Missile Defense initiative. It is well mirrored in the on-going Sino-US debate regarding the deployment of THAAD in South Korea. ${ }^{71}$ Some people would expect the similar breakdown of Eastern European socialist regime in North Korea. The current situation is totally different from that of the Eastern European countries in the early 1990s, because their socialist regimes were suddenly demolished following the destruction of the Soviet Union. The international community should focus on abolishing North Korea's nuclear weapons program before Pyongyang miniaturizes a nuclear warhead. This will be possible if they adhere to the "two-track approach." Going back to the sprit of the Geneva Agreed Framework and the September 19 Joint Statement is the starting point. The longer they maintain silence, the more they will witness an escalation of the nuclear crisis.

68 J. Schogol \& K. Miller, 315,000 U.S. and South Korean troops begin massive exercise as North threatens war, MARINE CORPS TimEs, Mar. 7, 2016, available at http://www.marinecorpstimes.com/story/military/2016/03/05/us-holds-militaryexercise-south-korea-north-threatens-war/81320402 (last visited on May 3, 2016).

69 Sung-jin Choi, Operations Plan 5015, Korea Times, Oct. 7, 2015, available at http://www.koreatimes.co.kr/www/ news/opinon/2015/10/202_188216.html (last visited on May 3, 2016).

70 U.N. Charter ch. VII.

71 Myo-Ja Ser, China reasserts its opposition to Thaad, Korea Joongang Daily, Apr. 2, 2016, available at http:// koreajoongangdaily.joins.com/news/article/article.aspx?aid=3017001 (last visited on May 3, 2016). 